\title{
Hyperlipidemia Preventing Activities of Standardized Ethanolic Extract of Red Spinach (Amaranthus tricolor L.): An in Vivo Study in Male Sprague-Dawley Rats
}

\author{
Aktivitas Pencegahan Hiperlipidemia dari Ekstrak Etanolik Bayam Merah \\ (Amaranthus tricolor L.) Terstandar: Studi In Vivo pada Tikus Sprague-Dawley Jantan
}

\author{
Dimas Adhi Pradana $^{1 *}$, Laily Apriani ${ }^{1}$, Sitarina Widyarini ${ }^{2}$ \\ ${ }^{1}$ Pharmacy Department, Faculty of Mathematics and Natural Sciences, Universitas Islam Indonesia, \\ Yogyakarta, Indonesia \\ ${ }^{2}$ Faculty of Veterinary Medicine, Universitas Gadjah Mada, Yogyakarta, Indonesia \\ *Email : dimas.pradana@uii.ac.id
}

Submitted: 10 Maret 2018

Revised: 17 Mei 2018

Accepted: 2 Juli 2018

\begin{abstract}
Lipid metabolism disorders can lead to hyperlipidemia that triggers atherosclerosis. This study aimed to identify the potential of standardized ethanolic extract of red spinach (Amaranthus tricolor L.) to prevent hyperlipidemia by referring to the reduction of triglyceride level and total cholesterols in male Sprague-Dawley rats. A total of 30 experimental animals was put into 6 groups, including normal, positive control $(0.9 \mathrm{mg} / \mathrm{kgBW}$ of simvastatin), negative control, treatment I (200 mg/kgBW of extract), treatment II ( $400 \mathrm{mg} / \mathrm{kgBW}$ of extract), and treatment III $(800 \mathrm{mg} / \mathrm{kgBW}$ of extract). Preventive therapy and positive control were administered from day 1 to day 67. Hyperlipidemia was induced by feeding pure lard and duck yolk to the rats twice daily from day 8 to day 67. Determination of triglyceride level and total cholesterols was conducted on day 0 and day 67 . The findings revealed that the treatment groups with ethanolic extract of red spinach at doses of $200 \mathrm{mg} / \mathrm{kgBW}$, $400 \mathrm{mg} / \mathrm{kgBW}$, and $800 \mathrm{mg} / \mathrm{kgBW}$ had statistically significant differences $(\mathrm{p}<0.05)$ compared to the negative control group. The treatment III group with a dose of $800 \mathrm{mg} / \mathrm{kgBW}$ showed the most reduction of total cholesterol and triglyceride levels, which was the same as the positive control group. In conclusion, standardized ethanolic extract of red spinach possessed preventive activities against atherosclerosis based on the total cholesterol and triglyceride parameters. The highest activity was demonstrated by the dose of 800 $\mathrm{mg} / \mathrm{kgBW}$ group.
\end{abstract}

Keywords: Rats; Red spinach; Hyperlipidemia; Total cholesterol; Preventive therapy; Triglyceride

\begin{abstract}
Abstrak
Gangguan metabolisme lipid dapat menyebabkan hiperlipidemia yang memicu aterosklerosis. Penelitian ini bertujuan untuk mengetahui potensi ekstrak etanol dari bayam merah (Amaranthus tricolor L.) untuk mencegah hiperlipidemia dengan parameter penurunan kadar trigliserida dan kolesterol total pada tikus Sprague-Dawley jantan. Sebanyak 30 hewan percobaan dimasukkan ke dalam 6 kelompok, termasuk kontrol positif normal $(0,9$ mg/kgBB simvastatin), kontrol negatif, perlakuan I (200 mg/kgBB), perlakuan II (ekstrak $400 \mathrm{mg} / \mathrm{kgBB})$, dan perlakuan III ( $800 \mathrm{mg} / \mathrm{kgBB}$ ekstrak). Terapi pencegahan dan kontrol positif diberikan dari hari ke-1 sampai hari ke-67. Hiperlipidemia diinduksi dengan pemberian lemak babi murni dan kuning telur kepada tikus dua kali sehari dari hari ke-8 sampai hari ke-67. Penentuan kadar trigliserida dan kolesterol total dilakukan pada hari ke-0 dan hari ke-67. Temuan tersebut menunjukkan bahwa kelompok perlakuan dengan ekstrak etanol dari bayam merah pada dosis $200 \mathrm{mg} / \mathrm{kgBB}, 400 \mathrm{mg} / \mathrm{kgBB}$, dan $800 \mathrm{mg} / \mathrm{kgBB}$ memiliki perbedaan yang signifikan secara statistik $(p<0,05)$ dibandingkan dengan kelompok kontrol negatif. Kelompok perlakuan III dengan dosis $800 \mathrm{mg} / \mathrm{kgBB}$ menunjukkan penurunan kadar kolesterol dan trigliserida paling banyak, sama dengan kelompok kontrol positif. Dapat disimpulkan bahwa ekstrak etanolik bayam merah terstandar memiliki aktivitas pencegahan terhadap aterosklerosis berdasarkan parameter kolesterol dan trigliserida total. Aktivitas tertinggi ditunjukkan oleh kelompok $800 \mathrm{mg} / \mathrm{kgBB}$.
\end{abstract}

Kata kunci : Bayam merah; Hyperlipidemia; Kolesterol total; Terapi preventif; Trigliserida 


\section{INTRODUCTION}

Hyperlipidemia is a condition in which the level of lipids in the plasma rises, including high levels of cholesterol and triglyceride. ${ }^{1}$ Increased lipid levels in the blood may lead to atherosclerosis, a risk factor associated with cardiovascular diseases. $^{2}$ Cardiovascular diseases are the leading cause of death globally. ${ }^{3}$ To prevent high triglyceride and cholesterol levels, healthy lifestyle and good dietary habits are recommended. In addition, consumption of antihyperlipidemia drugs and traditional therapy using medicinal plants is believed to be able to reduce cholesterol levels. Herbal medicinal products and supplements have been massively used as the first-line treatment by approximately $80 \%$ of global population in the last three decades. The efficacy of some herbal products have been recognized, showing the great potential of medicinal plants in therapies; however, many others have yet to be tested or monitore. ${ }^{4}$ In fact, standardization is required to guarantee the quality of natural ingredients used in herbal products. Standardization ensures that the end products (drugs, extracts, or extract products) have constant parameters with guaranteed quality and safety. A standardized natural ingredient can be developed into products that benefit the society. ${ }^{5}$ In other words, a standardized natural ingredient has come closer to a possibly marketable herbal product. One of the diseases that can be empirically treated using such ingredient is hyperlipidemia.

Red spinach (Amaranthus tricolor L.) is one of the potential herbs for preventing increased levels of blood lipids. It contains a wide range of active ingredients, including vitamins, niacin, minerals (calcium, manganese, phosphor, and iron), fibers, carotenoids, chlorophyll, alkaloids, flavonoids, saponins in the leaves, and polyphenols in the stems. ${ }^{6}$ There have been only few studies of the preventive actions of red spinach against hyperlipidemia while it, in fact, has enormous potential for development since prevention is better than cure. This present study therefore aimed to examine the effects of administering a standardized ethanolic extract of red spinach (Amaranthus tricolor L.) as a preventive effort against increased total triglyceride and cholesterol to male Sprague-Dawley rats induced with high-lipid diet.

\section{METHODS}

\section{Materials and equipment}

This study used red spinach leaves, blue tip, $70 \%$ ethanol, mobile phase of methanol:ethanol (2:1), filter paper, cholesterol, pure lard, masker, microtube, LDL reagent, BR-II feed, gloves, silica gel $\mathrm{F}_{254}$, simvastatin, injection syringe, and oral syringe. The equipment included Pyrex glass, TLC chamber, Eppendorf tube, heating mantel (MTOPs, Gopal), rat observation cage, micropipette, capillary pipe, rotary evaporator (Heidolph with Heizbad WB type), centrifuge, analytical balance (Mettler Toledo with PL 303, Dragon 205 type), and material scale.

\section{Research subjects}

Inclusion criteria for the rats were Sprague-Dawley, male, healthy, aged 2-3 months, weighing 150-250 grams, obtained from one breeding place, and equally fed. The exclusion criteria would apply when the subjects were unhealthy during the adaptation phase.

\section{Research procedure}

This study has obtained an ethical clearance from the Health and Medical Research Ethics Committee of Islamic University of Indonesia (No. 88/Ka.Kom.Et/70/KE/III/2016).

Leaves of fresh red spinach were washed, aerated, dried, and milled to obtain powder. Weighing 20 grams in a filter paper bag, the powder was then put into a Soxhlet extractor along with the solvent (70\% ethanol). Ethanol was used 
as solvent due to its universality and remarkable capability of extracting quercetin. The ratio of powder to ethanol was 1:10, circulated seven times. A rotary evaporator was used to concentrate the extract residue at $60^{\circ} \mathrm{C}$ and $60 \mathrm{rpm}$. To obtain a paste-like texture, the viscous extract was evaporated on a water bath followed by weighing, packing in a glass container, and storing in a desiccator. ${ }^{7}$

\section{Total cholesterol and triglyceride}

Triglyceride level was examined using the Colorimetric Enzymatic Test "GPO" with spectrophotometry. This method works according to the principle of triglyceride measurement after an enzymatic breakdown by lipoproteinase. Chinonimine from the catalyzation of 4aminoantipyrine by hydrogen peroxide became the indicator in this study. Meanwhile, the total cholesterol level in the serum was identified using the CHODPAP method with spectrophotometry and measured in $\mathrm{mg} / \mathrm{dl}$. Total cholesterol and triglyceride levels were measured on day 0 and day 67. Grouping of experimental animals shown in Table 1.

\section{Result analysis}

The Kolmogorov-Smirnov test was used to identify the normality of total cholesterol and triglyceride data. Significance values higher than 0.05 indicate normally distributed data. In addition, the paired t-test statistically identified the effect of extract administration prior to and following the treatment.

\section{RESULTS AND DISCUSSION}

The results of standardization become a reference to establish that the ethanolic extract of red spinach has been standardized according to the standardization criteria based on the parameter values, which are presented in Table $2 .^{8}$

Table 1. Grouping of experimental animals

\begin{tabular}{|c|c|c|}
\hline No & Group & Protocols \\
\hline 1 & Normal Control & Rats were fed standard BR-II and water ad libitum for 67 days. \\
\hline 2 & Positive Control & $\begin{array}{l}\text { Rats were induced by high-fat diet and duck yolk for } 60 \text { days since } 8^{\text {th }} \\
\text { day. Two hours prior to induction, } 0.09 \mathrm{mg} / \mathrm{kgBW} \text { simvastatin was } \\
\text { administered. }\end{array}$ \\
\hline 3 & Negative Control & $\begin{array}{l}\text { Rats were fed high-fat diet and duck yolk for } 60 \text { days starting from } 8^{\text {th }} \\
\text { day. }\end{array}$ \\
\hline 4 & Intervention 1 & $\begin{array}{l}\text { Rats were induced by high-fat diet and duck yolk for } 60 \text { days since } 8^{\text {th }} \\
\text { day. A dose of } 40 \mathrm{mg} / 200 \mathrm{gBW} \text { ethanolic extract of red spinach was } \\
\text { given two hours before induction (once a day). }\end{array}$ \\
\hline 5 & Intervention 2 & $\begin{array}{l}\text { Rats were given high-fat diet and duck yolk for } 60 \text { days starting day } 8 \text {. } \\
\text { Administration of } 80 \mathrm{mg} / 200 \mathrm{gBW} \text { ethanolic extract of red spinach was } \\
\text { done two hours prior to induction (once daily). }\end{array}$ \\
\hline 6 & Intervention 3 & $\begin{array}{l}\text { Rats were fed high-fat diet and duck yolk for } 60 \text { days since day } 8 \text {. Two } \\
\text { hours prior to induction, } 160 \mathrm{mg} / 200 \mathrm{gBW} \text { ethanolic extract of red } \\
\text { spinach was given (once a day). }\end{array}$ \\
\hline
\end{tabular}


Table 2. Standardization of ethanolic extract of red spinach leaves

\begin{tabular}{|c|c|c|c|c|}
\hline No & Parameter & Result & Reference & Note \\
\hline \multirow[t]{10}{*}{1.} & Specific Parameter & & & \\
\hline & a. Organoleptic & Odor: distinct spinach & - & Suitable \\
\hline & & Taste: bitter & & \\
\hline & & Color: greenish black & & \\
\hline & & Texture: viscous & & \\
\hline & b. Yield & $12.24 \%$ & - & Suitable \\
\hline & c. Chromatographic pattern & $R f$ Value: $0.74-0.81$ & - & Suitable \\
\hline & d. Quercetin content & $29.29 \%$ & - & Suitable \\
\hline & $\begin{array}{l}\text { Water-soluble extractive } \\
\text { value }\end{array}$ & $24.38 \%$ & $>7 \%$ & Suitable \\
\hline & $\begin{array}{l}\text { Ethanol-soluble extractive } \\
\text { value }\end{array}$ & $12.06 \%$ & $>2.5 \%$ & Suitable \\
\hline \multirow[t]{9}{*}{2.} & Non-specific Parameter & & & \\
\hline & a. Density & $1.388 \mathrm{~g} / \mathrm{ml}$ & $\begin{array}{c}\text { > density of water } \\
\qquad(1 \mathrm{~g} / \mathrm{ml})\end{array}$ & Suitable \\
\hline & b. Moisture content & $14.07 \%$ & $5-30 \%$ & Suitable \\
\hline & $\begin{array}{l}\text { c. Acid-insoluble ash } \\
\text { d. Microbial contamination }\end{array}$ & 0.51 & $1 \%$ & \\
\hline & $\begin{array}{l}\text { 1) Yeast-fungal } \\
\text { contamination }\end{array}$ & $<10^{-2} \mathrm{CFU} /$ gram & $<10^{-2}$ colonies $/ \mathrm{g}$ & Suitable \\
\hline & 2) MPN coliform & Negative & $<5 \times 10^{2}$ colonies $/ \mathrm{g}$ & Suitable \\
\hline & e. Metal contamination & & & \\
\hline & 1) $\mathrm{Pb}$ & $<0.096$ & $<10 \mathrm{mg} / \mathrm{kg}$ & Suitable \\
\hline & 2) $\mathrm{Cu}$ & 16.70 & $<50 \mathrm{ppm}$ & Suitable \\
\hline
\end{tabular}

\section{Hyperlipidemia preventive activity test}

The antihyperlipidemia activity test for the ethanolic extract of red spinach leaves was conducted for 67 days. In the first 7 days, ethanolic extract of red spinach leaves was given without induction to the treatment groups I, II, III, and simvastatin was administered without induction to the positive control group. From day 8 to day 67 , ethanolic extract of red spinach leaves and simvastatin were given with induced lard after 2 hours followed by oral induction of high-cholesterol diet (duck yolk) after 7 hours of extract administration. Sampling of blood serum was performed on day 0 and day 67 . The rats were neither induced nor given a therapy, they were only fed with food and water ad libitum instead. Total cholesterol is one of the observed parameters to identify hyperlipidemia. The difference in total cholesterol levels between pretreatment and post-treatment is presented in Table 3.

The data in Table 3 shows that the negative control group had the highest increase in total cholesterol level compared to the other groups, reaching $66.29 \mathrm{mg} / \mathrm{dl}$. Such condition indicates that the induction of high-fat diet was able to raise the cholesterol level. The greatest decrease in cholesterol level occurred to the positive control group (simvastatin) with $22.92 \mathrm{mg} / \mathrm{dl}$ reduction of total cholesterol level. Meanwhile, the administration of $800 \mathrm{mg} / \mathrm{kgBW}$ of red spinach extract to the treatment group III could reduce $19.44 \mathrm{mg} / \mathrm{dl}$ cholesterol, marking it as the most significant decrease. Table 4 also shows the statistical 
significance values obtained from the Paired Samples t-test to describe the significant differences before and after the treatment. The results indicate that only the normal group had insignificant difference between day 0 and day 67 $(p>0.05)$ while the other groups experienced the opposite $(\mathrm{p}<0.05)$.

Triglyceride is also one of the parameters to identify a hyperlipidemia condition. The differences between pretreatment and post-treatment are presented in Table 4, and the significance was analyzed using the Paired Sample t-test. Table 4 indicates that the negative group had the most significant increase in triglyceride level, reaching $89.02 \mathrm{mg} / \mathrm{dl}$, compared to the other groups. The induction of high-fat diet consisting of lard and duck yolk could increase the triglyceride levels in rats. With -18.6 $\mathrm{mg} / \mathrm{dl}$ decrease, the positive control group administered with simvastatin became the group with the most significant triglyceride level reduction, followed by the treatment group III with $-17.46 \mathrm{mg} / \mathrm{dl}$ reduction after given $800 \mathrm{mg} / \mathrm{kgBW}$ of extract and induced with high-fat diet. The statistical significance is also presented in Table 5 after an analysis using the Paired Sample T-Test. The normal group and the treatment group II had insignificant differences between day 0 and day 67 ( $p>0.05)$, but the other groups experienced the opposite $(p<0.05)$. Administration of high fat and egg yolk leads to increased total cholesterol and triglyceride levels. The decrease in total cholesterol and triglyceride levels depends on the doses of the extract; the higher the dose, the higher potential it has in preventing hyperlipidemia.

Table 3. Mean of total cholesterol levels on day 0 and 67

\begin{tabular}{lcccc}
\hline \multirow{2}{*}{ Groups } & \multicolumn{4}{c}{ Mean of Total Cholesterol Levels } \\
\cline { 2 - 5 } & Day 0 & Day 67 & $\Delta$ & Sig. \\
\hline Normal & $72.94 \pm 4.88$ & $69.18 \pm 6.14$ & -3.76 & 0.089 \\
Negative & $80.78 \pm 6.93$ & $147.07 \pm 7.60$ & 66.29 & $0.000^{*}$ \\
Positive & $78.72 \pm 6.39$ & $55.80 \pm 6.22$ & -22.92 & $0.001^{*}$ \\
Treatment I (P1) & $73.72 \pm 5.95$ & $80.64 \pm 5.29$ & -6.92 & $0.003^{*}$ \\
Treatment II (P2) & $69.98 \pm 4.77$ & $66.02 \pm 6.24$ & -3.96 & $0.006^{*}$ \\
Treatment III(P3) & $69.56 \pm 5.93$ & $50.12 \pm 8.40$ & -19.44 & $0.002^{*}$ \\
\hline
\end{tabular}

Note : All the means of cholesterol levels in rats are in $\mathrm{mg} / \mathrm{dl}$

$\Delta$ : Difference in mean cholesterol levels in rats between day 0 and day 67

* : Statistically significant difference between day 0 and day 67

Table 4. Mean of triglyceride levels \pm SD before and after the therapy and induction of high-fat diet (day 0 and day 67)

\begin{tabular}{lcccc}
\hline \multirow{2}{*}{ Group } & \multicolumn{4}{c}{ Mean of Total Triglyceride Levels } \\
\cline { 2 - 5 } \multicolumn{1}{c}{ Day 0 } & Day 67 & $\Delta$ & Sig. \\
\hline Normal & $62.12 \pm 7.64$ & $60.76 \pm 6.57$ & -1.36 & 0.439 \\
Negative & $63.94 \pm 7.84$ & $152.96 \pm 7.81$ & 89.02 & $0.000^{*}$ \\
Positive & $64.78 \pm 5.2$ & $46.18 \pm 2.81$ & -18.6 & $0.004 *$ \\
Treatment I (P1) & $59.9 \pm 6.15$ & $69,06 \pm 8.27$ & 9.16 & $0.019 *$ \\
Treatment II (P2) & $64.58 \pm 4.86$ & $63.02 \pm 13.23$ & -1.56 & 0.755 \\
Treatment III (P3) & $58.5 \pm 4.92$ & $41.04 \pm 4.55$ & -17.46 & $0.002 *$ \\
\hline
\end{tabular}

Note : All the means of triglyceride levels in rats are in $\mathrm{mg} / \mathrm{dl}$

$\Delta$ : Difference in mean triglyceride levels in rats between day 0 and day 67

* : Statistically significant difference between day 0 and day 67 
The mechanism of action of quercetin in reducing total cholesterol levels includes its ability to inhibit the secretion of apo B-100 in $\mathrm{CaCO}_{2}$ cells and to reduce the activity of MTP in forming cholesterols. In addition, quercetin is capable of restraining the activity of HMG-KoA reductase, an enzyme playing a role in cholesterol production, and quercetin can function as an antioxidant to combat free radicals. ${ }^{9,10}$ Furthermore quercetin can function as antioxidants that suppress the release of reactive $\mathrm{O}_{2}$ thus reducing endothelial dysfunction by inhibiting the initiation of oxidative chain reactions and therefore preventing the production of more macrophages. Antioxidants also decrease the toxicity of oxidative LDL against endothelial cells as well as reduce oxidative degradation due to nitric oxide. ${ }^{11,12}$

\section{CONCLUSION}

The standardized ethanolic extract of red spinach (Amaranthus tricolor L.) has the potential as a preventive therapy for atherosclerosis based on the total cholesterol and triglyceride parameters in male Sprague-Dawley rats. Higher extract dose leads to higher potential to prevent increased total cholesterol and triglyceride levels. This study found that the optimum dose of ethanolic extract of red spinach leaves was $800 \mathrm{mg} / \mathrm{kgBW}$ in the treatment group III.

\section{ACKNOWLEDGMENT}

We acknowledge Directorate of Research and Community Service UII for the research funding and Laboratory of Pharmacology, Pharmacy Program Universitas Islam Indonesia, for the facilities that have been given.

\section{REFERENCES}

1. American Heart Association, et al. Prevention and treatment of high cholesterol (hyperlipidemia). American Heart Association, Dallas, 2017.
2. Nelson RH. Hyperlipidemia as a risk factor for cardiovascular disease. Prim Care. 2013;40(1):195-21

3. Benjamin EJ, Blaha MJ, Chiuve SE, Cushman M, Das SR, Deo R, et al. Heart disease and stroke statistics2017 update: a report from the American Heart Association. Circulation. 2017 Mar 7;135(10):e146-e603. doi: 10.1161/CIR.0000000000000485.

4. Ekor M. The growing use of herbal medicines: issues relating to adverse reactions and challenges in monitoring safety. Front Pharmacol. 2013;4:177.

5. Kumar G, Singh YK, Prabhat P, Ali MR, Kumar M. Natural Product and Health-A Review on All Aspects. Current Research in Pharmaceutical Sciences. 2013;3(3): 68-79.

6. Alam S, Krupanidhi K, Sambasiva Rao KRS. Evaluation of in-vitro antioxidant activity of Amaranthus tricolor Linn. Asian J Pharmacol Toxicol. 2013;1(1):12-6.

7. Pradana DA, Anggriani ID, Setyaningrum TR. Potential of red spinach leaves ethanolic extract (Amaranthus tricolor L.) as a complementary therapy For Hiperlipidemia: Study in Vivo of histopathologic and activity of Alanin Aminotransferase (ALT). J Sains Farm Dan Klin. 2016;3(1):6-13.

8. Pradana DA, Pondawinata $\mathrm{M}$, Widyarini S. Red spinach (Amaranthus tricolor L.) ethanolic extract as prevention against atherosclerosis based on the level of Low-Density Lipoprotein and histopathological feature of aorta in male Sprague-Dawley rats. In: AIP Conference Proceedings. AIP Publishing; 2017. p. 020079

9. Bentz AB. A review of quercetin: chemistry, antioxidant properties, and bioavailability. J Young Investig. 2009;19(10):1762-70.

10. Yunarto N, Elya B, Konadi L. Potensi fraksi etil asetat daun gambir sebagai 
antihiperlipidemia. Jurnal Kefarmasian Indonesia. 2015;5(1):1-10

11. Asmariani WG, Probosari E. Pengaruh pemberian buah pepaya (Carica papaya L.) terhadap kadar kolesterol LDL dan kolesterol HDL pada tikus Sprague-Dawley dengan hiperkolesterolemia. Journal of Nutrition College. 2012;1(1):257-264.

12. Yunarto N, Aini N. Effect of purified gambir leaves extract to prevent atherosclerosis in rats. Health Science Journal of Indonesia. 2015;6(2):10510

13. Kusuma AM, Asarina Y, Rahmawati YI, Susanti S. Efek Ekstrak Bawang Dayak (Eleutherine palmifolia (L.) Merr) dan Ubi Ungu (Ipomoea batatas L) terhadap Penurunan Kadar Kolesterol dan Trigliserida Darah pada Tikus Jantan. Jurnal Kefarmasian Indonesia. 2016; 6(2):108-16. 